\title{
Elderly care services in the netherlands and projection for the future in Turkey
}

\author{
Yasemin Kavlak* \\ Elderly Care Department, Health Services Vocational Schools, Eskisehir, Eskisehir Osmangazi University, Turkey
}

\begin{abstract}
As in other countries of the world, lifespans have been gradually extending in our country. The transition of the traditional family structure into the core family, and economic conditions, have started to make it compulsory for the eldery to receive care not in their own home but in a nursing home. However, the loneliness of the elderly in nursing homes requires serious financial resources in addition to problems such as feeling abandoned. Therefore, examining policies developed by countries that have faced the same problems before and creating a synthesis according to our own cultural structure would be the most appropriate approach. This study examines a European Union Project conducted in the Netherlands called "Evaluation and Development of Elderly Care Services within the Process of a Changing Health System" and coded 2011-1-TR1-LEO03-27100, between the dates 26/02/2012 and 03/10/2012, and discusses this project with the support of the literature.
\end{abstract}

\section{Introduction and General Information}

Aging is an inevitable process in which individuals gradually lose their physiological and spiritual powers irreversibly. The person's previous state of health, illnesses he/she had, accidents and surgical interventions, health-related habits and behaviors, and genetic factors contribute to these physiological changes [1].

The elderly are one of the most vulnerable groups in society. Vulnerability is not only associated with health problems. As people grow old, changes are observed in their behavioral adaptability. Changes in social position and social roles start with aging. Social relationships diminish, the social environment narrows down, and new relationships become difficult to establish; the individual's retirement and becoming distant from the labor force, and loss/deprivation of status come into question [2].

The growth rate of the elderly population is higher than the world growth rate of the general population. The annual growth rate of people aged 65 and over is $2.3 \%$, while the world population increases by $1.3 \%$ each year. The population of people aged 80 and over has been increasing every year at a rate of $3.5 \%$. The growth rate of the elderly population (65 years and older) in Turkey was recorded as $3.5 \%$ in 1960, 6.0\% in 2006 (DPT, 2008) and $8.3 \%$ in 2016 (TUIK, 2016) [3-5].

Especially in the First and Second World Wars and their aftermath, countries both in Europe and in other regions of the world lost hundreds of thousands of young and mature people. This situation has emerged as one of the reasons for changes in the structure of the population [6]. In addition, technological innovations and inventions that accelerated after the Second World War have ensured the improvement of living conditions. Prevention and early diagnosis and treatment of diseases, scientific and technological developments in the field of health, higher levels of education, the increasing number of people making use of social security, the decrease in the fertility rate and infant mortality with the development of preventive health services have led to a rise in the age of death, as all these are positively reflected in the average life expectancy $[7,8]$.
Societies are divided into four groups according to their elderly population ratio:

1 - Young societies: The population of those aged 65 and over is less than $4 \%$.

2 - Adult societies: The population of those aged 65 and over is between $4-7 \%$.

3 - Aged/elder societies: The population of those aged 65 and over is between $7-10 \%$.

4 - Very aged/old societies: The population of those aged 65 and over is more than $10 \%[9]$.

European Union (EU) countries have been defined as "very old societies" for many years. According to the statistics made in 2016; The ratio of the population aged 65 years and over to the total population is 19.2 in 28 European countries (Table 1).

While Turkey took its place in the "adult societies" class in 2007, it has been in the "aged/elder society" class since 2012 [8]. Based on the aging rates of European countries, it is expected that the elderly population rate in Turkey will rise from $7 \%$ to $14 \%$ in 27 years (Table 2). It is quite striking that this transition period will be faster for Turkey than for European countries $[8,10]$. These demographic changes result in the elderly having a more important role within the population, and thus, an important backdrop in terms of social policy practices is emerging. The problems of the elderly are not that discrete from the problems of the young. Increasing our knowledge about ageing helps us understand the aging process of the people around us and the

${ }^{*}$ Correspondence to: Yasemin Kavlak, Elderly Care Department, Health Services Vocational Schools, Eskisehir, Eskisehir Osmangazi University, Turkey, Tel: 902222393750; E-mail: ykavlak@hotmail.com

Key words: ageing, ageing policy, elderly care services, social policies, social state

Received: March 29, 2018; Accepted: April 10, 2018; Published: April 15, 2018 
Table 1. Rates of the Population Aged 65 and Above in EU and Some EU Countries

\begin{tabular}{|c|c|}
\hline COUNTRIES & RATES (\%) \\
\hline EU-28 & 19.2 \\
\hline Germany & 21.1 \\
\hline Sweden & 19.8 \\
\hline Spain & 18.7 \\
\hline France & 18.8 \\
\hline Finland & 20.5 \\
\hline Denmark & 18.8 \\
\hline Netherlands & 18.2 \\
\hline Ireland & 13.2 \\
\hline Turkey & 8.2 \\
\hline
\end{tabular}

Table 2. Ageing Rate in Some Countries and in Turkiye

\begin{tabular}{|c|c|c|c|}
\hline Countries & $\begin{array}{c}\text { Year of attainment } \\
\text { to } \mathbf{7 \%}\end{array}$ & $\begin{array}{c}\text { Year of attainment } \\
\text { to } \mathbf{\% 1 4}\end{array}$ & $\begin{array}{c}\text { Period of Transition } \\
\text { (Year) }\end{array}$ \\
\hline France & 1865 & 1980 & 115 \\
\hline Germany & 1930 & 1975 & 45 \\
\hline Sweden & 1890 & 1975 & 85 \\
\hline England & 1930 & 1975 & 45 \\
\hline U.S. & 1945 & 2020 & 75 \\
\hline Turkey & 2012 & 2039 & 27 \\
\hline
\end{tabular}

problems related to this process; it may also make us feel responsible for changing these negative conditions [11].

One of the most important social problems experienced during the elderly period is eldercare. Within the traditional family institution, the position and status of the elder are assured. As the family's most knowledgeable and experienced individual, the elder is treated with respect and at the same time he/she is a person whose needs are satisfied. In the core family structure, the elder has to sustain his/her life separately. This means that the elderly will not receive the support of their primary (family) and secondary (relatives) environment as before. Beside the core family model, the emergence of singleparent families also leads to the disappearance of supports seen in the traditional sense. Even the quantitative and proportional increase of the elderly population that cannot take place within the active population means the elderly will only take part in the consumer group in terms of macroeconomics. Therefore, in countries where the dependency ratios of the elderly population is high, the elderly are thought to be burdens for the working age population, as they do not have any contribution to the national income $[6,12]$.

Another framework that forms the basis of social policies devoted to the elderly is the acceptance of the "social state" principle, especially in developed countries. States adopting this principle have felt obliged to improve their citizens' socio-economic status, provide a life with dignity, and ensure social security. Recently, one of the principles that has become prominent in eldercare is that their appreciation and empowerment as individuals of the society to which they add value, materially and spiritually, are a moral requirement $[13,14]$.

In our country, the elderly are nursed by institutions or by their families and relatives. Within the process of social development, developing new models devoted to eldercare, intensifying nursing homes, day care centers and home care services, supporting care within family and setting standards for the quality of care given in institutions are requirements.

Social services provided in the countries of the European Union are seen in two ways: the "national health services" and "health insurance systems". In national health services, health care is provided that covers the whole population and is financed through taxes under one organizational integrity and plan; while in the second one (health insurance systems) health care services, which are mainly financed by premiums, are offered through a series of social insurance funds [15].

Elders who are 65 and over, with a chronic disease requiring longterm care, benefit from "home care" services. Among those receiving home care services, the proportion of those aged 65 and over was $83 \%$ in Austria, 78\% in Germany, and 63\% in the United States in 1998. Home care services include not only medical services but also social services. Home care given by experts (formal care) and home care given by family members (informal care) can be offered as short and long term [16].

As a result of research with elderly individuals, it can be said that the eldercare programs established with the intent of training professional teams in order to develop more qualified and efficient care methods, either at home or in institutions, and to implement these methods, are among the best steps taken in this field.

\section{Elderly Care Services Offered in the Netherlands}

Citizens aged 65 and over comprised $15.8 \%$ of the 15.8 million population of the Netherlands. It is estimated that the rate will rise to $23 \%$ by 2025 .

In the Netherlands, due to the increase in life span, the utilisation age for eldercare services has been set at 67 years and older. However, if a person has a disability or chronic disability, he/she can benefit from these services from the age of 55. In the Netherlands, deductions from wages of working individuals are made by the government for pension and health expenditures. In addition, each individual has to pay premiums to a private insurance company; otherwise the state will impose sanctions on the individual. While the main framework of the health services that will be offered is determined by the state, the services are actually provided by private insurance companies and municipalities. Only $4.4 \%$ of the funding for the social services budget is based on taxes, while $74.8 \%$ is based on insurance premiums [17-19].

Long-term social care or high cost medical treatment and care services have been guaranteed by a law enacted on January 1, 1968. This law created a comprehensive social security model against the risk of requiring care/needing nursing by way of taking social care sevices into the scope of practice, first with retirement homes and nursing homes in 1980 , and then with private homes in 1989 [20].

Without making a distinction among the sick, disabled and elderly, all people in need of nursing are legally protected. Criteria such as the general health of the person, status of care dependency due to illness, psychological and social functions, and home and environment conditions are taken into consideration in terms of necessity for constant care. If care is required for at least two and a half hours a day or a home visit is required at least three times a day, all care costs are covered by health insurance, just as in institutional care services [17,21].

Standard assessments for care services are carried out by regional assessment bodies allied to insurance companies. After an individual's eligibility for nursing is determined, a care allowance in the name of the person can be received. With this allowance, the person can get external care services from family members, independent professional caregivers, civil society organizations or from nursing companies.

Within the scope of social care services at home, home nursing, personal basic care, household cleaning, health care services, medical treatment and rehabilitation, day care, assistive equipment and 
night care are included. The aim of social care services is to increase the quality of care and to ease caregivers' burdens (usually family members) with the help of technological equipment that simplifies the process of nursing either in nursing homes or at home by creating an institutionalised contemporary care system.

Organizations offering home care service in the Netherlands are obliged to fulfill three criteria:

1) Within social care services, the institution should be able to offer services designed to ease nursing, loan assistive equipment, improving and supporting health together with nursing care, personal care (assisting with daily life activities), and household affairs.

2) Social security of the care staff should be granted and the provisions regarding nursing within agreements or treaties such as social laws, regulations and collective bargaining, should be obeyed.

3) The institution should offer the appropriate quality of care in compliance with the specified "Standard Care/Nursing Models". Standard Care/Nursing Models are formed through examining nursing activities and services in practice, within the psycho-social context, and by surveying the positive-negative effects of those activities and services for the related person and his/her social environment.

The instutions offering care services in the Netherlands are regularly controlled by the authorities. Every organization has to create quality standards within their internal systems, review these standards at regular intervals and improve them. In addition, regulations regarding price determination and creating quality standards are made by the national government. The Netherlands, where the life expectancy is 80 for women and 78 for men, is classified as a "very old society". Therefore, for the satisfaction of both health and nursing needs, significant funding and interdisciplinary research in this area are needed.

University: These carry out the function of developing eldercare cost structures and strategies. Here, the questions of how aging can be understood academically and how the costs of eldercare can be reduced are studied. Within the context of master's degree programs that are offered at universities, researchers receive education in the subjects of geriatrics, gerontology and health care and improve their academic, clinical and managerial skills.

House doctor: These physicians offer primary healthcare services as family physicians in Turkey. In the Netherlands, an individual who would like to receive healthcare services is obliged to apply to the house doctor first. When these house physicians find it necessary, they can suggest hospitalization, home care or institutional care. In the Netherlands, primary health care services are offered by house doctors, secondary care services are offered by hospitals and tertiary care services are offered by university hospitals.

Geriatric doctor: They offer primary health care services to the elderly after completing a three-year geriatrics training program. Especially in a multinational country like the Netherlands, preparing proper diets in accordance with ethnic characteristics and religious beliefs, forming special events groups, educating families of the elderly about home care, and organising meetings in which families of the elderly can come together to discuss and share their problems are among the activities of geriatrics physicians.

University hospitals: After completing their education in the Faculty of Medicine, there is a five-year period of geriatrics specialization training. One year of this education is completed as psychiatric training. Individuals over the age of 65 with multiple health problems, cognitive decline, falling, polypharmacy and increased mobility problems are accepted to geriatric clinics. Patients are admitted to the service for a maximum of eight days; if the problem is under control and the patients do not need nursing anymore, they can be discharged from the hospital (to their homes), but if they need constant supervision and care they are sent to nursing homes. Thanks to the well-equipped laboratories in these clinics, without spending time, energy and money for diagnosis and treatment at different clinics, it is possible for the elder to be assessed in detail and at the same time it is possible to determine the most appropriate treatment protocol for him/her. When the doctor diagnoses a disease other than geriatric problems, he/she sends the patient to other relevant departments.

Municipalities: In the Netherlands, due to education and working life, cities consist of young people while in rural areas, the average age is higher. Therefore, municipalities play a very important role in the services provided to the elderly. The main theme of providing services is to serve the elder at home. Although there are differences among service providers in terms their strengths, services offered are as follows:

a) Right to have free rides on buses and trains: Such a practice is supported to encourage the elderly to not to stay at home all the time, in order for them to have a social life and to do their own work as much as possible.

b) Scooter mobile service: Devices that are something between an electric wheelchair and a motorcycle and allow the elderly to wander and shop in the city easily, are procured by the social services of municipalities and given to the elderly who are in need.

c) Taxi service is offered to promote participation in special organisations/events such as going to the theater and visiting relatives. The taxi invoices are paid by the municipality.

d) To transport people who are disabled, there are specially designed vehicles within municipalities that offer service when needed.

e) Housekeeping support: In Rotterdam around 25,000 people receive this support. When a person would like to have such a service, he/she gets in contact with one of the companies offering this service; then the company informs the municipality and the house doctor determines which kind of support the person should have and how long he/she should have it. In accordance with the prescription determined by the house physician, the municipal social services department requests these services from the company and in this way, the elder can have housekeeping service. The bill for the service provided by the company is covered by the municipality.

f) To patients who require 24-hour nursing, institutional care is given.

g) Support for family nursing: If a person is looking after his/her parents, the municipality supports the person in some ways such as paying the caregiver's insurance, and providing health care service and medical equipment at a reduced price.

h) For volunteers who will nurse the elderly person (who may also be family members), municipalities organize training courses consisting of theoretical knowledge and nursing practice (how is an elderly person laid down on the bed?, how is he/she fed?, what are the methods of bathing?, proper nourishment).

i) Support groups: They aim to create groups where families with similar problems can gather and share their problems and develop solutions under the supervision of professionals. 
j) Counseling centers: These are units that inform the public about the municipality's support services and how to benefit from them.

k) Due to the fact that the biggest problem of ethnic groups is that they do not know the local language and they are very dependent on their own traditions, municipalities plan and enforce unique service programs in order to serve these groups.

Home care and consulting companies: This kind of company serves individuals whose need for home care is approved by a unit called Zay Sed, belonging to municipalities.

a) Nursing services: In line with the order specified by the house doctor, medical practices and nursing care services are offered by individuals who have received nursing training.

b) Care service: This is the unit responsible for personal care and hygiene.

c) House cleaning: Any kind of housework, shopping and cooking that the elder cannot do by himself/herself is in the scope of this service, within the boundaries determined by the social service. People working in this service should know the language and work with a more experienced person for a while.

d) Social counseling: The participation of the elder is required in activities involving the control of the wealth/money of the elder, to make hospital arrangements or to plan for him/her to spend time with his/her peers.

e) Psychological support department: This consists of psychiatrists and psychologists. Their duty is to create solutions for problems of the elderly or their caregiving family members.

Apart from these services, they undertake the duty of organizing and training the volunteer caregivers. Training basically involves teaching the caregivers proper methods for taking care of the elder/ patient by using their own bodies (in terms of both physical and psychological states) more ergonomically and economically.

Moreover, these institutions offer solutions for problematic individuals by meeting with the municipal officials once a month.

Elderly apartments: This is a system in which the person lives not in a nursing home but in his/her own environment, where he/she can control his/her own life. As a rule, only individuals age 50 or over can live in these apartments. The property and maintenance of the houses is the responsibility of the state, and those staying in these houses pay rent. If the individuals would like to receive home care services, personal care or household jobs are billed to the municipality according to the type of care offered. In these houses, many things have been specially designed for the elderly. For example, the heating system operates with electricity so there is no gas to be left on/open. In bathrooms, there are handles placed against the risk of falling down and alarm systems that can be easily reached in case of any immediate danger. In this way, a safe, comfortable living environment is provided where the elder can receive the necessary care services in his/her own house.

Nursing home: Nursing homes are composed of independent sections (just like the ones in elderly apartments): every one room or two rooms suite belonging to the resident consists of a bathroom, toilet and kitchen. Every floor has a lounge, common bathroom and toilet. In addition, there is a dining room, a cafeteria, a small supermarket, a hairdresser, a physiotherapist and a social events lounge. There is a private section/department within the body of the nursing home where they provide care for the elderly with dementia who need more nursing. It is easy to enter this section; however, in order to leave it there is a security code for the door.This precaution is taken for the safety of elderly residents with dementia. There are alarms inside the rooms and on the elderly themselves ${ }^{\mathrm{s}}[22]$.

Care center: The elderly whose nursing cannot be done in nursing homes and who need more care are taken to the care center. Apart from this, the elderly who have completed their requirement for hospital care but need nursing for a longer time, and those having no possibility of living on their own, are accepted to the care center temporarily and remain there until they get better. Upon completion of the recovery process, the elderly either go back to their home, or they are supported with home care service or according to their current state; they also benefit from other services of the institution [22].

The institutes employ psychologists, physiotherapists, dietitians, doctors, nurses, social service experts and administrators. There are nurses who have been trained in elder care and other nurses working under the direction of these eldercare nurses, in addition to the main "hospital nurses." These nurses take care of the elderly patients' personal needs and also administer their medication and feed them. Only these nurses are on duty at night. Social services experts and doctors also deal with the problems of elders who reside in the nursing home's district [22].

Civil society organizations or churches: Without any profit motive, theseorganizations offer places where the elderly come together to socialize. In addition, they nurse patients who are housebound and need home care, and they meet the nourishment and household needs of these patients. These institutions, which are quite well organized, are financed through donations and their activities are supported by the state and municipalities.

Food delivery service to the home: Meals are prepared in the main kitchen, placed on plates while they are hot and distributed to the homes of the elderly by volunteers. A volunteer leaves a weekly menu with the elderly person every Monday, and the person marks the food they would like to have from the list.The volunteer collects the lists and delivers them to the main kitchen on the following day. The volunteer distributes the food according to this list for a week. The patients give their keys to the volunteers so that they can reach their elderly patients easily. Providing food service also ensures social oversight. Every day, one volunteer knocks on the doors of the elderly living alone and by doing so, can see whether they are safe and sound or not, or whether they are alive or not [22].

This service actually seems quite close to our tradition of offering a bowl of food cooked in our own homes to our neighbours. In fact, this quite humanistic approach is operated entirely systematically in the Netherlands; therefore, personal doubts disappear to ensure that the elderly who cannot cook for themselves are fed properly and regularly.

As developed European Union countries estimate that the burden of nursing the elderly will reach levels that cannot be handled for economical and social reasons, the general approach to eldercare is moving away from institutional care. In these countries, the aim is for professional services to be offered first by the relatives of the patients and then by volunteers, in their own environments or homes. Social protection is provided to the elderly by improving physical housing conditions and improving living standards. Social policies for the elderly are discussed within the context of this social protection. With respect to care insurance targeting the support of the family, they include the legal regulations in their social policies $[17,18]$.

Factors such as rural depopulation due to industrialization and urbanisation, women's entrance into the workforce, core families taking 
the place of extended families, housing contraction, and weakening of domestic relations have left family members unable to take care of the elderly in their homes, which results in elderly individuals moving into nursing homes in higher proportions in Turkey [23-25]. Faced with problems like remaining in an institution, a decrease in social support, loss of socio-economic status, decrease in social contacts, and care dependency, social care and support aimed at the elderly have come to be more and more important [26].

In Turkey, the Society for the Protection of Children (Himaye-i Etfal Cemiyeti) was founded in 1921 to identify and protect the people in need of protection. Later, the society was renamed the Social Services and Child Protection Agency and began to serve within the framework of a new job description: "the determination of children, handicapped and elderly who need protection, care and assistance; ensuring their protection, nurture, upbringing and rehabilitation", as stated in article 9, subclause b of the Social Services Act, published in the Official Gazette on 27/05/1983. With subclause (f) of article number 10 of the law and under the framework of "the determination of the elderly being in social and economical poverty; regulating, following, coordinating and auditing the services related to their nurture and protection", the job description of the Department of Eldercare Services in the Social Services and Child Protection Agency has been described in detail.

Improvement of existing services for the elderly and efforts to launch new services are executed under the framework of four regulations, which are:

- Turkish Social Service and Children Protection Institution Nursing Homes and Nursing Home YB and RM Regulation,

- Private Nursing Homes and Elderly Care Centres Regulation,

- Regulation on Establishment and Functioning Rules of Nursing Homes that will be established within the body of State Institutions and Organizations

- Regulation on Day Care and Home Care Services that will be offered in Eldercare Centers [21,27].

Within the framework of the "International Plan of Action on Ageing " prepared for the Second World Assembly on Ageing arranged by the United Nations on 8 - 12 April, 2002, in Madrid, "Situation of Elderly People in Turkey and National Action Plan on Aging" was prepared by the "National Committee on Aging," with the participation of the Department of Elderly Services, related state institutions and civil society organizations under the coordinatorship of the Undersecreteriat for State Planning Organization, and was enacted in 2007 by the Higher Planning Council. In our country, in accordance with the results of the Action Plan and Workshop, studies on the implementation of the results of the Action Plan and Workshop on Aging are continuing with the intent of establising the "National Institute on Aging" [28,29].

In Turkey, an important step has been taken on this issue for the first time, as handicapped and elderly people (who are in need of nursing) having been included within the scope of care insurance in the social security system without social contributions through the "Disabled People Act" adopted by The Grand National Assembly of Turkey aimed at protecting individuals in need of care $[18,26]$. In recent years, "Regulation on the Presentation of Home Care Services" [30] entered into the Official Gazette dated 10/03/2005 and numbered 25751 and "Directive/Guideline on Implementing Procedures and Principles of Home Health Care Services" [31] entered in 01.02.2010 are proof of the efforts made in executing services aimed at the elderly, according to the system in our country. Especially, since 2010, thanks to home health care services carried out via Provincial Health Directorates, elderly individuals now have easy access to health services, and examinations, tests, treatment, medical care and rehabilitation of those in need can be received in the individiuals' homes and family environments.

\section{Conclusion and Recommendations}

1) In social policies related to the elderly, the role of actors such as state and local governments and families varies across countries. Social care services for the elderly are increasingly usng "mixed care models." In this context, on the one hand, the state (central/local) contributes in terms of either finance or direct service in care services, while on the other hand the relatives of the elder do so.

2) In the Netherlands, there is no special training branch for elderly care service; the education is received as nursing training and categorized in terms of professional responsibilities and rights by years. However, in our country, there is a foundation degree (twoyear vocational high school) called "eldercare technician" consisting of elderly-specific theoretical knowledge and clinical practice. Thus, there is the opportunity to offer more unique, qualified and affordable services to the elderly.

3) In Turkey, elderly care services can be converted into a service industry for other countries (for foreigners) through changing government policies; thus health tourism can be promoted.

4) For Turks who immigrated from Turkey and live in Europe without speaking the local language of the country, being nursed by educated individuals knowing the patients' traditions and language will improve the expected benefits from care and the quality of life of the elderly.

5) In European countries, the view that elderly people being nursed in their own living spaces (if possible) is quite important in terms of their psychology has begun to predominate in recent years.

6) Families are expected to have a more active role in caring for the elderly with the mixed care model, which has been begun to be adopted throughout the world. In our country, because of our traditional family structure, the elderly are nursed within the family as far as possible; therefore, they, and they participate in the treatment process more actively as their psychological health is much better. Considering the experiences of European Union countries, we think that adopting a care system to support the home care of the elderly, paying attention to caregivers' social or economical needs and extending the scope of social security, will increase the quality and accessibility of care services.

\section{Acknowledgments}

Authors of 26.02.2012 and 03.10.2012 made an inspection trip to Holland. "Changing Health Care System in the Process of Elderly Care Services Evaluation and Development" named and 2011-1-TR1LEO03-27100-coded this study project (trip) by the European Union supported. The authors review what they have learned on the trip wrote comparing with applications in Turkey and were supported by literature.

\section{Disclosure Statement}

The authors declared no conflicts of interest with respect to the authorship and/or publication of this article. 


\section{References}

1. Arslantas D (2012) Açikögretim Fakültesi Yayini No: 1462, Yasli ve Hasta bakim Hizmetleri, Yasli Bakiminda Temel Bilgiler, 26-47.

2. Uçku R (2012) Açikögretim Fakültesi Yayini No: 1462, Yasli ve Hasta bakim Hizmetleri, Yasli Bakiminda Temel Bilgiler, 2-25.

3. DPT (2008) Ekonomik ve Sosyal Göstergeler (1950- 2006), http://ekutup.dpt.gov.tr/ ekonomi/gosterge/tr/1950-06/esg.htm, 2008.

4. Yaslilar I (2016) http://www.tuik.gov.tr/PreHaberBultenleri.do?id=24644.

5. Beger T, Yavuzer H (2012) Yaslilik ve Yaslilik Epidemiyolojisi, Klinik Gelisim 25 1-3

6. Altan ÖZ (2006) Sosyal Politika, Anadolu Üniversitesi Yayinlari, Eskisehir.

7. Seyhun ÖK (2006) Avrupa Birligi'ndeki Demografik Dönüsümün Türkiye'nin Avrupa Birligi'ne Üyeligi Çerçevesinde Isgücü Piyasalarina Yansimasi. Türkiye Cumhuriyet Merkez Bankasi Uzmanlik Tezi, TCMB Dis Iliskiler Genel Müdürlügü Yayinlari, Ankara.

8. Akin F (2010) Yaslilara Yönelik Sosyal Politikalar: Isveç, Almanya, Ingiltere ve Italya Örnekleri. Çalisma ve Toplum 1: 175- 202.

9. EUROSTAT (2017) Data extracted in June 2017, http://ec.europa.eu/eurostat/statisticsexplained/index.php/Population_structure_and_ageing

10. Akgün S, Bakar Ç, Budakoglu II (2004) Dünyada ve Türkiye'de Yasli Nüfus Egilimi, Sorunlari ve Iyilestirme Önerileri. Türk Geriatri Dergisi 7: 105-110.

11. Altan, ÖZ, Sisman Y (2003) Yaslilara Yönelik Sosyal Politikalar, Kamu-Is Is Hukuku ve Iktisat Dergisi 7: 2-36.

12. Altan ÖZ (2004) Sosyal Politika Dersleri, Anadolu Üniversitesi Yayinlari, Eskisehir.

13. Lloyd L (2004) Mortality and Morality: Ageing and the Ethics of Care. Ageing \& Society 24: $235-256$

14. Mccullough LB (2002) Long-Term Care Ethics, Encyclopedia of Aging (Vol. 3), Eds. Ekerdt DJ, et al., USA, 844-847.

15. Bosco A (1998) Saglik Bakim Sistemleri, Çev. Evren Balta, Avrupa'da Sosyal Koruma; Degisim ve Sorunlari, ETUC-ETUI Konferansi, Ed. Bosco A, Hutsebaut M, Harb-Is Yayinlari, ss. 317-326.

16. Oglak S (2007) Uzun Süreli Evde Bakim Hizmetleri ve Bakim Sigortasi. Türk Geriatri Dergisi 10: 100-108.
17. Seyyar A, Oglak S (2004) Danimarka ve Hollanda Sosyal Güvenlik Sistemlerinde Bakim Hizmetleri (Mukayeseli Bir Degerlendirme), ÖZ-VERI Dergisi; T.C. Basbakanlik Özürlüler Idaresi Baskanligi; 1.

18. http://www.ozida.gov.tr/yayinlar/ozveri/ovlmakdanholsosyal.htm.

19. Seyyar A (2010) Dünyada ve Türkiye'de yasliliga bagli bakim sorununa karsi güvence sistemleri.

20. Dursun A (2005) Avrupa'da Yasli Bakimi - Saglik Turizmi Dernegi, www. saglikturizmi.org.tr/media/Pdf/6.pdf?.

21. Bakima Muhtaçlik Sorununa Genel Bir Bakis, Engelli ve Yasli Hizmetleri Gene Müdürlügü, http://www.eyh.gov.tr/tr/8248/Bakima-Muhtaclik-Sorununa-Genel-BirBakis.

22. Seyyar A (2006) Degisen Dünyada ve Türkiye'de Sosyal Politikalar, Degisim Yayinlari, Istanbul.

23. Sezgin G (2017) Council of International Fellowship Cif Hollanda Mesleki Ve Kulturel Degisim Programi (Yaslilik ve Özürlülük Alani).

24. Tu YC, Wang RH, Yeh SH (2006) Relationship between perceived empowerment care and quality of life among elderly residents within nursing homes in Taiwan: A questionnaire survey. Int J Nurs Stud 43: 673-680. [Crossref]

25. Aylaz R, Günes G, Karaoglu L (2005) Huzurevinde yasayan yaslilarin sosyal, saglik durumlari ve günlük yasam aktivitelerinin degerlendirilmesi. Inönü Üniversitesi Tip Fakültesi Dergisi 12: 177-183.

26. Kavlak Y, Demirtas N (2012) Huzurevinde Kalan Yaslilarda Günlük Yasam Aktiviteleri, Depresyon ve Bilissel Durumun Yasam Kalitesi Üzerine Etkileri, Sakaryamj 2: 30-36.

27. Görgülü Ü, Akyar I, Akdemir N, Sun Kapucu S (2010) Dünyada ve ülkemizde yaslilara yönelik politikalar. Türk Fiz Tip Reh Derg 56: 30-33.

28. Kanunu SH (1983) Tarih: 27/5/1983, Sayi: 18059, http://www.mevzuat.gov.tr/ MevzuatMetin/1.5.2828.pdf.

29. Çohaz A (2010) Türkiye' de Yasli ve Yaslilara Sunulan Bakim Hizmetleri.

30. Plani E (2007) Türkiye' de Yaslilarin Durumu ve Yaslanma Ulusal Eylem Plani, Sosyal Sektörler ve Koordinasyon Genel Müdürlügü, DPT Yayinlari.

31. Tarihi G (2005) Evde Bakim Hizmetleri Sunumu Hakkinda Yönetmelik.

32. Tarihi G (2016) Saglik Bakanliginca Sunulan Evde Saglik Hizmetlerinin Uygulama Usul ve Esaslari Hakkinda Yönerge.

Copyright: $@ 2018$ Kavlak Y. This is an open-access article distributed under the terms of the Creative Commons Attribution License, which permits unrestricted use, distribution, and reproduction in any medium, provided the original author and source are credited. 